\title{
CANADIAN ANAESTHETISTS' SOCIETY \\ ANNUAL MEETING 1974 \\ RESIDENTS' PROGRAMME PRIZES
}

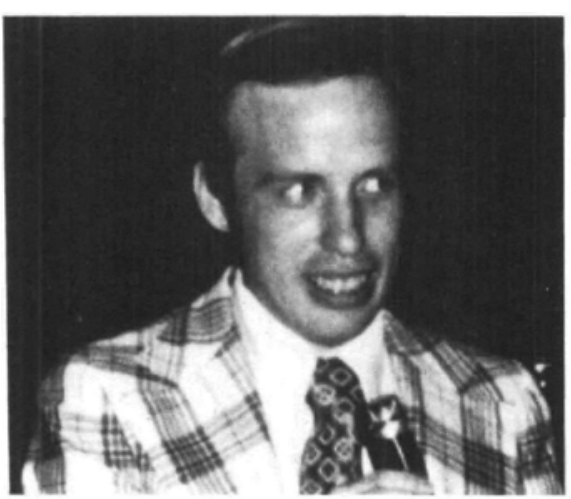

DR. R.L. KNILL

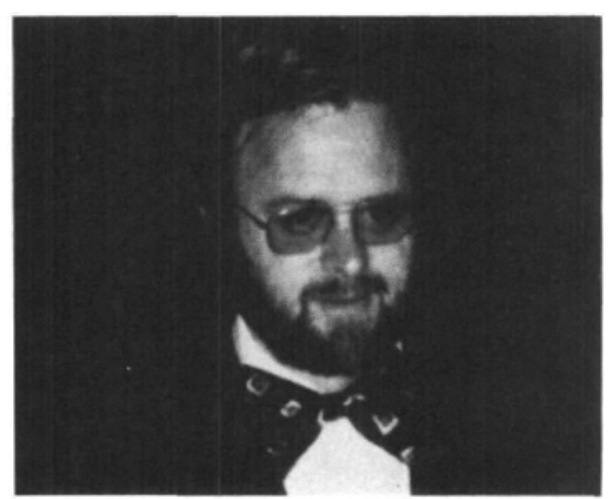

Dr. J. BoYce

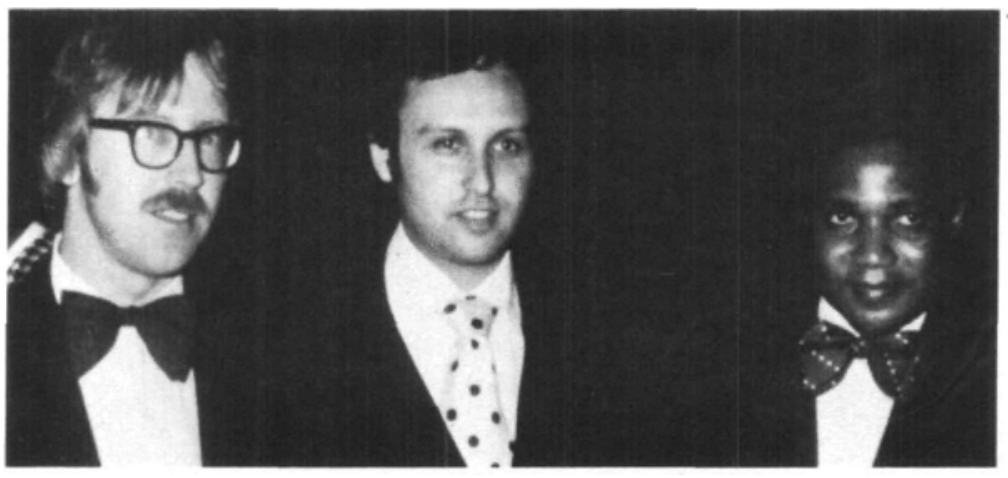

Dr. J.B. Smith, Dr. H.R. Wexleh, Dr. H.M. Chinyanga

Prizes for papers in the Residents' Programme at the Annual Meeting were presented on the occasion of the Annual Dinner at St. John's on June 19, 1974. The presentations were made by Dr. Paul Otton of McGill University, Chairman of the Scientific Programme Committee. The winners pictured above were Dr. R.L. Knill, University of Toronto (1st Prize); Dr. J. Boyce, Queen's University (2nd Prize); Dr. J.B. Smith, University of Manitoba, Dr. H.R. Wexler, University of Toronto, and Dr. H.M. Chinyanga, University of Toronto (shared 3rd Prize).

Les prix pour les présentations à la séance des Résidents lors du Congrès Annuel, ont été présentés au Banquet officiel, le 19 juin à St Jean, Terreneuve. Le Dr Paul Otton de l'Université McGill, qui était chargé du programme scientifique, a fait les présentations des prix. Les gagnants dont les photos apparaissent ci-dessus furent le Dr R.L. Knill de l'Université de Toronto (ler prix), le Dr J. Boyce de l'Université Queen, (2ième prix); les Drs J.B. Smith de l'Université du Manitoba, Dr H.R. Wexler, Université de Toronto et H.M. Chinyanga, Université de Toronto, ont partagé le 3ième prix. 